University of Michigan Law School

University of Michigan Law School Scholarship Repository

\title{
Discerning a Dignitary Offense: The Concept of Equal 'Public Rights' during Reconstruction
}

\author{
Rebecca J. Scott \\ University of Michigan Law School, rjscott@umich.edu
}

Available at: https://repository.law.umich.edu/articles/2238

Follow this and additional works at: https://repository.law.umich.edu/articles

Part of the Constitutional Law Commons, Law and Race Commons, Legal History Commons, and the State and Local Government Law Commons

\section{Recommended Citation}

Scott, Rebecca J. "Discerning a Dignitary Offense: The Concept of Equal 'Public Rights' during Reconstruction." Law \& Hist. Rev. 38, no. 3 (2020): 519-53.

This Article is brought to you for free and open access by the Faculty Scholarship at University of Michigan Law School Scholarship Repository. It has been accepted for inclusion in Articles by an authorized administrator of University of Michigan Law School Scholarship Repository. For more information, please contact mlaw.repository@umich.edu. 


\title{
Discerning a Dignitary Offense: The Concept of Equal "Public Rights" during Reconstruction
}

\begin{abstract}
REBECCA J. SCOTT
The law school not being open to his race, he would take the common-sense law on the subject, and interpreted "public rights" to signify the right to be treated as one of the public without distinction of color.
\end{abstract}

New Orleans Times, December 29, $1867^{1}$

1. New Orleans Times, December 29, 1867, Supplement, 1.

Rebecca J. Scott is Charles Gibson Distinguished University Professor of History and Professor of Law at the University of Michigan $<$ rjscott@umich.edu $>$. The author thanks Jeremy Adelman, John K. Bardes, Jack Beermann, David Blight, Pamela Brandwein, Richard Brooks, Amy Chazkel, Nathalie Dessens, Laura Edwards, Sam Erman, Jeffrey Fagan, Eric Foner, Malick Ghachem, Thavolia Glymph, Jean M. Hébrard, Thomas Holt, Beth Kressel Itkin, Martha S. Jones, J. Morgan Kousser, Charles Lane, Richard Lempert, Davide Maldarella, Kate Masur, Christopher McCrudden, Kristi Richard Melancon, Julian Davis Mortenson, Edgardo Pérez-Morales, Marina Pino, Marieke Polfliet, Lawrence Powell, Richard Primus, Gautham Rao, Peter Railton, Michael Ross, Mark Roudané, George Rutherglen, Romy Sánchez, A. K. Sandoval-Strausz, Christopher Schmidt, Thomas Scott-Railton, Joseph Singer, Miranda Spieler, and Amy Dru Stanley. She is also grateful to participants in workshops at the Center for Advanced Study in the Behavioral Sciences, at Columbia University Law School, and at the University of Michigan Law School, and to the anonymous reviewers for Law and History Review. The staff of the Bibliothèque Royale de Belgique in Brussels; Alexa Pearce and Maura Seale of the Harlan Hatcher Library; and Marina Hunt, Virginia Neisler, Katie Reineck, and Seth Quidachay-Swan of the University of Michigan Law Library were all very helpful. Florence Jumonville, formerly of the Special Collections Department of the Library of the University of New Orleans, offered guidance in the manuscript records of the Louisiana Supreme Court. Bryan LaPointe and Priya Khangura provided able research assistance, and Jeanette Diuble and Ruthie Freeman helped with manuscript preparation. The author gratefully acknowledges the generous support of the William W. Cook Endowment of the University of Michigan Law School. 
The mountain of modern interpretation to which the Fourteenth Amendment of the United States Constitution has been subjected tends to overshadow the multiple concepts of antidiscrimination that were actually circulating at the time of its drafting. The subsequent development of a "state action doctrine" limiting the reach of federal civil rights enforcement often eclipses important contemporary understandings of the harms that Reconstruction-era initiatives were meant to combat. ${ }^{2}$ One distinctive and radical mode of formulating what we would now call anti-racism developed through discussion centered in wartime and early Reconstruction Louisiana. Without waiting for federal constitutional guarantees, the delegates to Louisiana's 1867-68 Constitutional Convention - fully half of whose members were men of African descent - crafted a set of legal tools with which to combat the reimposition of what they saw as practices of "caste" incompatible with the values of a democratic republic. This was a constitution-making process in which the newly enfranchised would be among those who wrote the new rules. ${ }^{3}$

The Bill of Rights that introduced Louisiana's 1868 state constitution declared that all of the state's citizens would be affirmatively guaranteed "the same civil, political, and public rights," independent of race or color. ${ }^{4}$ The last element in the triad of civil, political, and public rights stands out. The familiar English-language lexicon of rights has often been characterized by variants on the grouping of "natural, civil, political,

2. Eric Foner, The Second Founding: How the Civil War and Reconstruction Remade the Constitution (New York: W. W. Norton, 2019), 1-20, 55-92, makes a similar point. For a recent critical perspective on the "state action doctrine," see Martha Minow, "Alternatives to the State Action Doctrine in the Era of Privatization, Mandatory Arbitration, and the Internet: Directing Law to Serve Human Needs," Harvard Civil Rights-Civil Liberties Law Review 52 (2017): 145-67. See also "Developments in the Law: State Action and the Public Private Distinction," Harvard Law Review 123 (2010): 1248-314. Pamela Brandwein, Rethinking the Judicial Settlement of Reconstruction (New York: Cambridge University Press, 2011), especially chapter 6, examines the historical traces of an alternate "state neglect" framework, which would bring protection from some private discriminatory action under Fourteenth Amendment guarantees.

3. Several scholars have explictly placed post-Civil War lawmaking in the framework of transitional justice, noting that the amendments to the federal constitution were crafted by a body that did not include any representatives of the groups whose rights were most immediately at stake. See Richard Primus, "The Riddle of Hiram Revels," Harvard Law Review 119 (2006): 1680-734; and John Fabian Witt, "The Achievements, and Compromises, of Two Reconstruction-Era Amendments," Washington Post, October 31, 2019, B.7.

4. See Constitution Adopted by the State Constitutional Convention of the State of Louisiana, March 7, 1868 (New Orleans: Printed at The Republican Office, 1868). The quoted phrase is in Title I, Art. 2. 
and social rights." ${ }^{5}$ Louisiana's 1868 Constitution broke with that typology, using the construct of "public rights" to encompass claims that might otherwise be deemed "social rights" in the language of the period. As one enthusiastic delegate to the 1867-68 Constitutional Convention put it, a guarantee of the same "public rights" should mean that "everywhere a white man can go or travel the colored man should go." 6 Although anathematized by conservatives as permitting unearned claims to "social equality," the 1868 text specified that all places of public accommodation or public transportation, and indeed all "places of business, or of public resort" operating under any license, were to be deemed "places of a public character" and open to the "accommodation and patronage of all persons, without distinction or discrimination on account of race or color."7

The debate over public rights and human dignity has a modern ring, but activists in Louisiana and elsewhere had already put it on the table 150 years ago. ${ }^{8}$ Blending together European and North American critiques of distinctions based on prejudices of caste, they asserted the right of access to a shared and social "common life." $\mathrm{New}$ Orleans had long been a nodal

5. For the assumption that "social rights" were generally beyond the scope of government action before the late nineteenth and early twentieth centuries, see Eric Foner, Reconstruction: America's Unfinished Revolution (New York: Harper Collins, 1988), 231. In his most recent work, Foner does address the concept of "public rights." Foner, The Second Founding, 13, 19, 94, 128, 140-42, 156. On the futility of drawing firm divisions among such categories of rights, see Richard A. Primus, The American Language of Rights (Cambridge: Cambridge University Press, 1999), especially 127-76; and Rebecca J. Scott, "Public Rights, Social Equality, and the Conceptual Roots of the Plessy Challenge," Michigan Law Review 106 (2008): 777-804.

6. See "This Convention. Twenty Fifth Day, The Constitution a Night Mare," New Orleans Times, December 28, 1867, Supplement, 1. The reporting in the New Orleans Times was hostile to public rights claims, and mocked their proponents. This quotation nonetheless seems consistent with statements by the delegate in question, Edward Tinchant, as recorded in the official proceedings of the convention. See the discussion of Tinchant in this article.

7. See Louisiana Constitution of 1868, tit. II, art. 13.

8. On the dignitary component of dispossession and exclusion, see Bernadette Atuahene, "Dignity Takings and Dignity Restoration: Creating a New Theoretical Framework for Understanding Involuntary Property Loss and the Remedies Required," Law \& Social Inquiry 41 (2016): 796-823. On harm imposed on individuals and communities by selective humiliation, see Center for Constitutional Rights, Stop and Frisk: The Human Impact. The Stories behind the Numbers, the Impact on Our Communities (New York: Center for Constitutional Rights, 2012) and Jeffrey Fagan, Floyd v. City of New York, 08 Civ. 1034 (SAS) (SDNY), October 2010. Tom R. Tyler, Jeffrey Fagan, and Amanda Geller, in "Street Stops and Police Legitimacy: Teachable Moments in Young Urban Men's Legal Socialization," Journal of Empirical Legal Studies 11 (2014): 751-85, at 756, emphasize the consequences of "assaults on dignity."

9. The phrase "common life" (which sounds much like the French vie commune, shared life or life of the community) appears in "No Separate Schools," Tribune, April 26, 1867, 
point of the circulation of people, a place where established ideas met new experiences. Through the language of "public rights," Louisiana's activists invoked an affirmative claim to public respect, reinforcing and expanding on common-law traditions of innkeepers' and streetcar conductors' duty to serve. In turn, their innovative constitutional text, transformed into a working concept through new state laws, provided the basis for a remarkable set of legal claims.

At stake, for the most insistent of the delegates, was their very dignity. ${ }^{10}$ Creating a constitutional "right to be treated as one of the public" implied a dignitary understanding of the refusal of service, and acknowledged that enforced public separation created stigma and upheld distinctions of "caste." Drawing on terms with deep resonance in the rhetoric of Europe's 1848 revolutions, these delegates named and rejected the public humiliation entailed in exclusion. Recognizing the key role that a forced performance of deference played in the white supremacist project, they wrote their claim to equal "public rights" into the constitution of this former Confederate state. ${ }^{11}$

4. English-speaking activists also used the word "caste" to critique practices of subordination. See "Later from the North," Picayune, July 2, 1862, 1; and "From Boston," Tribune, May 25, 1865, 1, reporting a speech by Wendell Phillips. The term continued to appear into the 1890s. On the need for juries free of the "bias, caste and prejudices incident to the same in this country," see "Afro-American Proclamation, Solemn and Extraordinary," Southwestern Christian Advocate (New Orleans), May 11, 1899, 2 (also cited in Thomas Ward Frampton, "The Jim Crow Jury," Vanderbilt Law Review 71 [2018]: 1593-694, at 1611). See also Scott Grinsell, “"The Prejudice of Caste': The Misreading of Justice Harlan and the Ascendancy of Anticlassification," Michigan Journal of Race and Law 15 (2010): 317-67, especially 339-53. On republicanism from a transnational perspective see David Prior, Between Freedom and Progress: The Lost World of Reconstruction Politics (Baton Rouge: Louisiana State University Press, 2019), Introduction.

10. On uses of the term in nineteenth-century Louisiana, see Rebecca J. Scott, "Dignité/ Dignidade: Organizing against Threats to Dignity in Societies after Slavery," in Understanding Human Dignity, ed. Christopher McCrudden (Oxford: For the British Academy by Oxford University Press, 2013), 61-77. See also the 1908 essay by Charles W. Chesnutt, "The Courts and the Negro," in his Essays and Speeches, ed. Joseph R. McElrath, Jr., Robert C. Leitz III, and Jesse S. Crisler (Stanford, CA: Stanford University Press, 1999), 262-70.

11. The phrase "right to be treated as one of the public" was attributed to "Mr. Tinchant, colored." "This Convention. Twenty Fifth Day, The Constitution a Night Mare," New Orleans Times, December 28, 1867, Supplement, 1. Activists writing in French often used phrases such as "haine de caste" (caste hatred) and "préjugé de caste" (caste prejudice). See for example "La Liberté," L'Union, October 18, 1862, 1; and "Nos Détracteurs," L'Union, January 13, 1863, 1. An exploration of anti-caste thinking in modern jurisprudence is Reva B. Siegel, "Equality Talk: Antisubordination and Anticlassification Values in Constitutional Struggles over Brown," Harvard Law Review 117 (2004):1470-1547, especially $1493,1504,1540$. 
The state's expanded electorate ratified the new text in April of 1868, months before the Fourteenth Amendment was added to the United States Constitution. Under the aegis of these state constitutional provisions, Louisiana's legislature promptly enacted statutes that specified that those who offered lodging, transportation, or entertainment to the public could "make no discrimination on account of race or color." State law granted victims of discrimination a cause of action under which they could seek both actual and "exemplary" damages. ${ }^{12}$

Legal ferment over the meaning and modes for achieving equal rights accompanied Reconstruction across the South and throughout the nation. ${ }^{13}$ Louisiana was not unique in this respect. Elements of "public rights" thinking were expressed in many jurisdictions by longstanding antislavery activists, and by early African American elected lawmakers. ${ }^{14}$ In Louisiana, however, this process built on a specific language shaped by long-standing transnational and comparative observation encompassing France, the United States, and the Caribbean. It might be anachronistic to say that the activists' observation of human rights practice shaped their human rights theory, but they drew on concepts developed inside and outside the United States, and on their own direct experiences, as they challenged racial discrimination.

12. An act "to enforce the Thirteenth Article of the Constitution of this State, and to regulate the Licenses mentioned in said Thirteenth Article," was approved on February 23, 1869. See La. Rev. Stat. No. 38 (1869).

13. For recent overviews on rights during Reconstruction, see Laura F. Edwards, A Legal History of the Civil War and Reconstruction: A Nation of Rights (New York: Cambridge University Press, 2015); and David Blight and Jim Downs, eds., Beyond Freedom: Disrupting the History of Emancipation (Athens, GA: University of Georgia Press, 2017). Other Reconstruction state legislatures also passed civil rights bills with public accommodations provisions, generally beginning in 1870. See Foner, Reconstruction, 370; and A. K. Sandoval-Strausz, "Travelers, Strangers, and Jim Crow: Law, Public Accommodations, and Civil Rights in America," Law and History Review 23 (2005): 53-94, 58.

14. As Thavolia Glymph points out in her article in this issue, South Carolina's 1868 Constitution employed the term "public privileges" with much the same intent: "Distinction on account of race or color, in any case whatever, shall be prohibited, and all classes of citizens shall enjoy equally all common, public, legal and political privileges." South Carolina Constitution of 1868, art. I, § 39. For documentary compilations that illuminate vernacular understandings of rights, see Ira Berlin, Leslie S. Rowland, et al., Freedom: A Documentary History of Emancipation, 1861-1867, 6 vols. to date (New York: Cambridge University Press; Chapel Hill: University of North Carolina Press, 1982-). On initiatives in the District of Columbia, see Kate Masur, An Example for All the Land: Emancipation and the Struggle over Equality in Washington, D.C. (Chapel Hill: University of North Carolina Press, 2010), 9, 87-126, 158-73. 
As an innovation in political language, the phrase "public rights" represented a claim to equal access to goods and services, whether offered by public or private providers. ${ }^{15}$ Although primarily aiming to eliminate differential treatment in the public sphere, proponents also sought to deflect the volatile charge that men and women of color were making a claim to "social equality," a term that in the Reconstruction South could carry overtones of physical intrusion into private spaces and sexual contact between Black men and white women. ${ }^{16}$

The "public rights" concept sought to define the line that demarcated the public from the private in such a way as to reaffirm the state's obligation to protect its citizens from humiliation based on prejudice when they sought services that were offered to the public. One advocate adroitly cited the 1866 federal Civil Rights Act, noting that it made no allusion that could legitimate "a distinction between men on account of race or color." $\mathrm{He}$ then stretched the interpretation of the federal bill's scope to argue that it "expressly provides that no such distinction shall ever be made in any public action whatever." The task of Louisiana's new state constitution, in his view, was to enable the legislature to target the prejudice that impeded fulfillment of the larger guarantee of equality. ${ }^{17}$

The state's responsibility for the licensing and regulation of private businesses helped to cast the net wide, but the boundary was not defined

15. The phrase "public rights" later appeared in the platform of the national Republican Party for two cycles (1872 and 1876), only to disappear thereafter. Kirk H. Porter and Donald Bruce Johnson, National Party Platforms, 1840-1964 (Urbana and London: University of Illinois Press, 1966), 46-47, 53-54. Pamela Brandwein analyzes the intraparty conflicts that yielded both a verbal endorsement of the concept (in language perhaps borrowed from Louisiana precedent) and a half-hearted pursuit of the goal. See Brandwein, Rethinking the Judicial Settlement, 60.

16. A vivid explication of this subtext of the phrase "social equality" is the short story by W. E. B. Du Bois, "On Being Crazy," The Crisis June (1923): 56-57. Opponents of various provisions charged, on the floor of the 1867-68 Constitutional Convention, that the public rights guarantee sought to impose "social equality." See the statement of Mr. Dearing explaining his vote against the Constitution, the protest of John T. Ludeling and John. L. Barret, and the repeated objections from Judge Cooley, endorsed by several of his colleagues; all in Official Journal of the Proceedings of the Convention for Framing a Constitution for the State of Louisiana (New Orleans: J. B. Roudanez and Co., 18671868), 278, 290-92.

17. See "Strike at the Root of Prejudice," Tribune, December 25, 1867, 4. This newspaper published sections in French and in English. Subsequent citations distinguish these as The Tribune or La Tribune. The 1866 act did not explicitly mention public accommodations or public action. See Civil Rights Act of 1866, ch. 31, 14 Stat. 27-30. For a modern study of the act that reads its guarantees as indeed being wide in scope, see George Rutherglen, Civil Rights in the Shadow of Slavery: The Constitution, Common Law, and the Civil Rights Act of 1866 (New York: Oxford University Press, 2013). 
exclusively through licensing. Article 13 of the 1868 Louisiana Constitution specified that it was the very offering of services and access to the public that gave an entity a "public character." 18 Subsequent statutes were less sweeping than Article 13, but they held that no provider of services who was operating under a state, parish (county), or municipal license would be allowed to discriminate among customers. ${ }^{19}$ The state thus asserted its jurisdiction over the conduct of licensed providers, seeking to assure that citizens would not be publicly marked as unworthy through the imposition of unequal terms of service. ${ }^{20}$

In prohibiting denials of equal service based on race or color, Reconstruction-era activists drew on long-standing common-law precedent concerning the duty to serve of common carriers and innkeepers. ${ }^{21}$ Louisiana's lawmakers made it clear that such providers' duties implied concomitant public rights, and that those rights could be claimed in court by individuals. ${ }^{22}$

18. Joseph William Singer points out the limitations of using the licensing function to define the boundaries of the duty to serve in "No Right to Exclude: Public Accommodations and Private Property," Northwestern University Law Review 90 (1996): 1283-497, especially 1315-21; and "We Don't Serve Your Kind Here: Public Accommodations and the Mark of Sodom," Boston University Law Review 95 (2015): 929-50. On frameworks for a cause of action against discrimination, see Amnon Reichman, "Professional Status and the Freedom to Contract: Toward a Common Law Duty of Non-Discrimination," Canadian Journal of Law and Jurisprudence 14 (2001): 79-132.

19. See La. Rev. Stat. No. 38 (1869). See also La. Rev. Stat. No. 84 (1873), “An Act to protect the civil rights of citizens. . making certain acts in violation of civil rights a misdemeanor and declaring the punishment therefor." Individual misbehavior, such as unruliness or drunkenness, remained permissible grounds for refusal.

20. On the licensing of businesses in the nineteenth century, see William J. Novak, The People's Welfare: Law and Regulation in Nineteenth-Century America (Chapel Hill: University of North Carolina Press, 1996), 90-95.

21. On contested interpretations of such duties, see Sandoval-Strausz, "Travelers, Strangers, and Jim Crow," 53-94; Masur, An Example for All the Land, 100-112; Kenneth W. Mack, "Law, Society, Identity, and the Making of the Jim Crow South: Travel and Segregation on Tennessee Railroads, 1875-1905," Law \& Social Inquiry 24 (1999): 377; and Kenneth W. Mack, "Rethinking Civil Rights Lawyering and Politics in the Era Before Brown," Yale Law Journal 115 (2005): 256.

22. See La. Rev. Stat. No. 38 sect. 3. ("That all licenses hereafter granted by this State, and by all parishes and municipalities therein, to persons engaged in business or keeping places of public resort shall contain the express condition that the place of business or public resort shall be open to the accommodation and patronage of all persons without distinction or discrimination on account of race or color. . ."). Conviction for violation of this condition was to lead to forfeiture of the license, and liability to civil suit. The 1873 statute charged the state attorney general with initiating suit for termination of license upon receipt of complaint from a citizen. See La. Rev. Stat. No. 84. 


\section{Transnational Dialogues}

As they developed the language of "public rights," Louisiana's bilingual (and occasionally trilingual) activists and legislators drew on their own experiences at home, and on voices from France, the islands of the Caribbean, and Belgium, with occasional contributions from Italy and Mexico. Some of the participants in these exchanges resembled what Daniel Rodgers, in a different context, has designated "cosmopolitan progressives," men and women who could serve as brokers of ideas across national boundaries. ${ }^{23}$ In the state's $1867-68$ constitutional moment, such mobile progressives were able to fuse their concerns with those of Louisiana-born Creole radicals and with a far larger group of newly enfranchised voters who had achieved their legal freedom during the Civil War. Together, they crafted a remarkable regime of rights, and fought to defend it across a decade of open confrontation with white supremacists.

For some in the activist community of New Orleans, the world of France, its empire, and its former empire provided a natural comparative example. For the most radical, the antislavery nation of Haiti (formerly the French colony of Saint-Domingue) served as an emblem of early assertions of civil equality and a refusal to defer to legalized white supremacy. ${ }^{24}$ At the same time, France itself could be figured as a place of republican principles and the defense of equality. Indeed, the initial pairing of the words "public" and "rights" may have built upon language used in the courses in constitutional law offered in Paris in the 1830s by the Italian-born liberal Pellegrino Rossi. ${ }^{25}$

23. See Daniel Rodgers, Atlantic Crossings: Social Politics in a Progressive Age (Cambridge, MA: Harvard University Press, 1998), 1. Rodgers focuses primarily on the English- and German- speaking North Atlantic. See also the concept of passeurs culturels in Louise Bénat Tachot and Serge Gruzinski eds., Passeurs culturels: mécanismes de métissage (Paris: Presses Universitaires de Marne-la-Vallée and Éditions de la Maison des sciences de l'homme, 2001).

24. Participants in the Haitian Revolution held many different ideas about freedom, rights, republicanism, monarchy, and property. Explicitly dignitary claims to equal treatment in the public sphere were central to the ideologies of some of the revolution's precursors, including Vincent Ogé (discussed in this article), and protagonists, including Julien Raimond. See John D. Garrigus, "Opportunist or Patriot: Julien Raimond (1744-1801) and the Haitian Revolution," Slavery and Abolition 28 (2007):1-21.

25. Rossi believed that all persons were eligible for such "public rights," which he saw as synonymous with "social rights," but he defined them in terms of "public liberties" rather than in terms of access to public accommodations and public respect. Pellegrino Luigi Edoardo Rossi, Oeuvres complètes, vol. 1 Cours de Droit Constitutionnel professé à la Faculté de Droit de Paris (Paris : Librairie de Guillaumin, 1866), 10. 
Already in 1848, dispatches from the French colony of Guadeloupe had brought to Louisiana the news that the victory of the republican revolution in Paris would bring a (second) French abolition of slavery. ${ }^{26}$ That abolition, moreover, was to be accompanied by the extension of citizenship to those formerly enslaved, and by a prohibition on the creation of obstacles to what was explicitly designated égalité sociale (social equality). ${ }^{27}$ Migrants and texts arriving from France to New Orleans in these years thus often brought a dose of quarante-huitard fervor and of hostility to aristocratic distinctions of "caste," coupled with a long-standing French concern with the legal protection of individual honor, now extended to those who would once have been thought to have no honor to protect. ${ }^{28}$

Little more than a decade later, the Civil War reached the heart of New Orleans, as a Union fleet under Flag Officer David Farragut broke through Confederate defenses and fought its way up the Mississippi River, bringing the city under federal control in April of $1862 .{ }^{29}$ Soon the Union Army began to recruit soldiers from within the ranks of the city's residents designated as free men of color. As bearers of personal honor and proponents of republicanism, men like the Louisiana-born, French-educated Joseph Tinchant stepped forward in 1863 to serve as officers in the 6th Louisiana Volunteers (Union), and quickly asserted their right to public respect. An observer of Joseph Tinchant's speeches later suggested that the contrast between Tinchant's prior experience of civil equality in France and his stigmatization in Louisiana animated his vigorous advocacy. This may well be true, but Joseph Tinchant had worked for years in Louisiana as a cigar merchant and as the treasurer of a school for children of color. Like free men and women of color in New Orleans and

26. For news from France and from the French Antilles, see the articles published in Le Courrier (New Orleans) on April 2, April 6, April 10, and April 11, and then on May 10, May 13, and May 31, all 1848.

27. See the decree issued by Minister Arago for Martinique "Circulaire Ministérielle No. 358," Bulletin Officiel de la Martinique, May 7, 1848, 594. See also Myriam Cottias, D'une Abolition, l'autre: Anthologie raisonnée de textes consacrés à la seconde abolition de l'esclavage dans les colonies françaises (Marseille: Agone Éditeurs, 1998).

28. See Marieke Polfliet, "Émigration et politisation: les Français de New York et La Nouvelle-Orléans dans la première moitié du XIXe siècle (1803-1860)" ( $\mathrm{PhD}$ diss., Université Nice Sophia Antipolis, 2013); and Rebecca J. Scott, "Asserting Citizenship and Refusing Stigma: New Orleans Equal-Rights Activists Interpret 1803 and 1848," in New Orleans, Louisiana and Saint-Louis, Senegal: Mirror Cities in the Atlantic World, 1659 to 2000s, eds. Emily Clark, Ibrahima Thioub, and Cécile Vidal (Baton Rouge: Louisiana State University Press, 2019), 146-67. On the concept of a "protectable interest" in one's personal honor, see James Q. Whitman, "Enforcing Civility and Respect: Three Societies," Yale Law Journal 109 (2000): 1279-398, at 1282.

29. See James M. McPherson, War on the Waters: The Union and Confederate Navies, 1861-1865 (Chapel Hill: University of North Carolina Press, 2012), 55-69. 
elsewhere who had never left the country, he had plenty of direct evidence of how public disrespect was aimed at undermining dignity. ${ }^{30}$

On the European side of the Atlantic, radical republicans and socialists were transfixed by the dramatic events of the United States Civil War and by the vast scope of the abolition of slavery that might result. Would the aftermath be full citizenship and égalité sociale, as had fleetingly seemed possible in the French Antilles? Moreover, for those in France who championed universal manhood suffrage in the face of sharp restrictions on the vote under Louis Napoléon Bonaparte, or who sought to expand the content of the citizenship granted to persons of African descent in the Antilles, the emergent debate over rights in the United States could be seen as renewing a version of their own fight. ${ }^{31}$

With federal authorities in control of New Orleans it became possible to say and publish many things that had previously been unspoken - or at least unwritten - in the city. Brothers Jean Baptiste and Louis Charles Roudanez founded a newspaper titled L'Union, and recruited Paul Trévigne, a fellow "free man of color," to serve as editor. Louis Charles Roudanez, who had apparently taken to the barricades in 1848 when he was studying medicine in Paris, brought to the new enterprise a keen sense of the importance of debates over civil equality. In the summer of 1864, L'Union, besieged by threats from white supremacists, ceased publication. Roudanez gathered a revised group of supporters, and opened a successor paper, now bilingual, calling it La Tribune/ The Tribune, also under the editorship of Trévigne. ${ }^{32}$

The pages of the Tribune reflected a community of discourse that was intensely transnational not just because of the movement of people, but also because of the movement of paper, which could transmit and translate ideas, literally and figuratively. The discussion unfolding in New Orleans

30. On recruitment to the Union Army, and the Tinchant family's frequent crossing of boundaries, see Rebecca J. Scott and Jean M. Hébrard, Freedom Papers: An Atlantic Odyssey in the Age of Emancipation (Cambridge, MA: Harvard University Press, 2012), ch, 6, especially 114-15. On claims of rights by free people of African descent, see Martha S. Jones, Birthright Citizens: A History of Race and Rights in Antebellum America (New York: Cambridge University Press, 2018).

31. The activist Melvil-Bloncourt, discussed in this article, provides an example of this kind of solidarity from afar. See more generally George M. Blackburn, French Newspaper Opinion on the American Civil War (Westport, CT: Greenwood Press, 1997), $57-73$.

32. Mark Charles Roudané, The New Orleans Tribune: An Introduction to America's First Black Daily Newspaper (Privately printed, 2014), 6, cites the information about Roudanez in Paris to an obituary written by Paul Trévigne, published in the New Orleans Daily Crusader, March 22, 1890. https://roudanez.com/the-new-orleans-tribune/ (accessed August 1, 2020). 
took place both in English and in French, at mass meetings and in pamphlets and the press. Although the advocates of full equality wrote alongside some of the cautious inheritors of a more accommodating (and elitist) tradition, the pages of the newspaper soon tracked the emergence of what would become a radical wing of the state Republican Party. For an interested observer in Paris or the French Antilles, all it took to join in the debate was a pen, paper, a postage stamp, and the mailing address of the Tribune. For Louisiana activists, in turn, the knowledge that their struggle reverberated overseas provided encouragement and a respite from the relentless hostility of former Confederates and conservative Unionists. ${ }^{33}$

The paper's readers, of course, were by no means all of one mind. In an acrimonious exchange of articles and letters Joseph Tinchant's younger brother Edward, born in France after their parents had fled the repression of antebellum New Orleans, challenged Armand Lanusse, an older Louisiana-born poet and school principal. Tinchant and Lanusse advanced diametrically opposed interpretations of the Union high command's recent demoting of men of color who had served as officers. Lanusse denounced the apparent unwillingness of the federal government to recognize the citizenship of the population of color, and called for men of color to leave Union-occupied New Orleans, where they could find no guarantee of respect, and move to French-occupied Mexico, where slavery had ended and the law made no distinctions of color. Edward Tinchant furiously repudiated this advice, identifying himself as a "son of Africa" and urging all men of color to stay at their posts in the United States and keep up the fight against slavery. ${ }^{34}$

Tinchant further denounced the imperialist project in Mexico that was being carried out by Louis Napoléon Bonaparte, now Napoléon III, whom he referred to as the "assassin of the 4th of December." This reference to the shooting of workers in the streets of Paris during Bonaparte's 1851 coup signaled Tinchant's identification with the radical wing of the 1848 Revolution, and reflected his assumption that his readers would recognize the reference to an emblematic struggle on the other side of the Atlantic. ${ }^{35}$ A correspondent writing from France later chimed in to argue that if men of color in Mexico were free citizens, it was not thanks to

33. On the community around the Tribune see Nathalie Dessens, "Louis Charles Roudanez, A Creole of Color of Saint-Domingue Descent: Atlantic Reinterpretations of Nineteenth-Century New Orleans," South Atlantic Review 73 (2008): 26-38; and Kristi Richard Melancon, "An African American Discourse Community in Black \& White: The New Orleans Tribune" (PhD diss., Louisiana State University, 2011).

34. The exchange between Lanusse and Tinchant is discussed in Scott and Hébrard, Freedom Papers, 121-39.

35. Ibid. 122-24. 
the French-installed Emperor Maximilian (formerly of Austria), but rather had been the accomplishment of the prior revolutionary-era President Guerrero, "un mulâtre" ("a mulatto"). ${ }^{36}$

In his polemic, Lanusse tried to embarrass Edward Tinchant by calling attention to an episode in 1863 during which Tinchant, in his United States army uniform, had been forced off a New Orleans streetcar by a white fellow soldier. Lanusse's goal was to discredit both the United States army and Tinchant himself, invoking the personal humiliation of the expulsion and Tinchant's inability to prevent it. But Tinchant replied that he had in fact been vindicated by his commanding officer, who rebuked the sergeant in question and threatened consequences if such actions were repeated. The entwining of personal honor, public respect, and public transport was already clear in this debate during the summer and fall of 1864 , at a time when federal policy on equal rights was quite undeveloped. $^{37}$

In the editorials, news items, and letters columns of the Tribune, individuals who were otherwise in the minority in their respective political worlds offered evidence and argument to develop the link between personal dignity and public respect. ${ }^{38}$ Moving back and forth between English and French, and working with young writers and typesetters willing to take great risks for the cause, the Tribune sought to fuse a patriotic pro-Union, pro-federal government stance with an open-ended rights-consciousness under the sign of the Haitian Revolution of 17911804, the French Revolution of 1848, and the most radical wing of transnational abolitionism. ${ }^{39}$

36. See Melvil-Bloncourt, untitled, from Phare de la Loire, October 4, 1865, as reprinted in La Tribune, December 30, 1865, 1 .

37. See Scott and Hébrard, Freedom Papers, 122-24; and Blair L. M. Kelley, Right to Ride: Streetcar Boycotts and African American Citizenship in the Era of Plessy v. Ferguson (Chapel Hill: University of North Carolina Press, 2010): 51-52. Struggles over access to streetcars had simultaneously emerged in the District of Columbia, which was similarly under direct federal authority. Congress took a step toward mandating equal rights on public transport in Washington, making the incorporation of the Metropolitan Railroad contingent on the adoption of an antidiscrimination provision. Masur, $A n$ Example for All the Land, ch. 3.

38. John K. Bardes cites an early petition to General George F. Shepley in which men of color protested the behavior of police who stopped them in the streets of New Orleans as presumptive "vagrants." The affront was not just the risk of imprisonment, but the very visible humiliation that came from being singled out for police attention on the grounds of color. See Bardes, "Redefining Vagrancy: Policing Freedom and Disorder in Reconstruction New Orleans, 1863-1868," Journal of Southern History 84 (2018): 69-112.

39. This was not a simple matter of "Latin" or "Gallic" idiosyncrasies in racial norms and social customs. Speakers of French could be as hostile to equal rights as any 
Despite their divisions, a substantial coalition of men of color-including the young Edward Tinchant - came together in 1864 under the leadership of Jean Baptiste Roudanez and Arnold Bertonneau to petition President Lincoln for the expansion of voting rights. A memorial appended to the petition asked that the right of suffrage be extended "not only to natives of Louisiana of African descent born free, but also to all others, whether born slave or free, especially those who have vindicated their right to vote by bearing arms, subject only to such qualifications as shall equally affect the white and colored citizens. $" 40$

In late 1864, Louis Charles Roudanez recruited as editor of the Tribune a strong-minded recent migrant from Belgium, Jean-Charles Houzeau, who would work at the paper alongside Paul Trévigne and concentrate on its English-language pages. Houzeau was unquestionably an oddity, an atypical individual whose ideas nonetheless distilled and shaped those of a wider group of activists. ${ }^{41}$ Before he became a newspaper editor in Louisiana, Houzeau had been a young man obsessed with astronomy and with natural history. Born in 1820 to a family of aristocratic lineage and liberal politics, he became a brilliant but restless student of the sciences, first in Belgium and then in Paris. After some time as a volunteer in the Observatoire de Bruxelles, and the publication of articles on astronomy based on his independent research, he took on a position as a paid assistant astronomer at the observatory in $1848 .^{42}$

Anglo-American resident or newcomer. See Polfliet, "Émigration et politisation," 128-30; and Scott, "Asserting Citizenship," 155-56.

40. A "Memorial” in Liberator, April 1, 1864, 3. Jari Honora, "“Cast Your Eyes Upon a Loyal Population': Lincoln and Louisiana's Free People of Color," La Créole, A Journal of Creole History and Genealogy 1 (2009): 1-8, transcribes the signatures. Given the ease of mistaking the cursive $\mathrm{n}$ for $\mathrm{u}$, and $\mathrm{t}$ for $\mathrm{d}$, the E. Tinchaud who appears on $\mathrm{p} .16$ is probably Edward Tinchant.

41. Houzeau's writings might be read in the light of Edoardo Grendi's argument for the study of exceptional documents that are revealing of the "normal." See Grendi, "Micro-analisi e storia sociale," Quaderni storici 12 (1977): 506-20, at 512. Jacques Revel rephrases this in terms of the exceptionnel normal, the otherwise marginal event or figure whose experience casts light on underlying processes. Jacques Revel, "Micro-analyse et construction du social," in Jeux d'échelles: La micro-analyse à l'expérience (Paris:Gallimard/Le Seuil, 1996): 15-36.

42. See the introduction by David Rankin in Jean-Charles Houzeau, My Passage at the New Orleans Tribune: A Memoir of the Civil War Era, ed. David Rankin, trans. Gerard F. Denault (Baton Rouge: Louisiana State University Press: 1984), 1-67; and Albert Lancaster, Notices biographiques sur J.-C. Houzeau (Brussels: F. Hayez, Imprimeur de l'Académie Royale de Belgique, 1889). A portion of Houzeau's correspondence is reproduced in Hossam Elkhadem, Annette Félix, and Liliane Wellens-De Donder, eds., Jean-Charles Houzeau: Lettres adressées des États-Unis à sa famille, 1857-1868 (Brussels: Centre National d'Histoire des Sciences, 1994). 
Houzeau's political activities in Belgium carried him beyond the boundaries of respectable liberalism and toward the circle influenced by the utopian socialist Charles Fourier, bringing what one later eulogist bluntly described as "compromising relations with men who were hostile to the institutions of the nation." ${ }^{33}$ The reference here was not only to the Fourierist Phalange with which Houzeau had associated himself, but also to a dramatic set of events that took place in Brussels on March 25, 1849. The otherwise relatively liberal King Leopold I of Belgium had become a resolute opponent of the revolutionary movement of 1848, and explicitly republican assemblies were seen by monarchists as provocations. Houzeau was responsible for the organization of one such "banquet," whose entrance fee was just 50 centimes (entitling the bearer to a small roll, a slice of ham, and unlimited water). The event opened with a public reading of the article of the Belgian Constitution that guaranteed the right of assembly. But the gathering was soon invaded by armed supporters of King Leopold and ended in disarray. In the aftermath, Houzeau was fired from his job at the Observatoire. ${ }^{44}$

Thus thwarted in his professional career, Houzeau took off on a hiking trip to Hungary with a group of friends, but that ended no better, given political upheaval in Hungary. ${ }^{45}$ After additional travels, he settled in Paris, and continued wide-ranging research on his own, with a particular interest in optical modes of telegraphic communication. This brought him into conflict with zealous police officers who doubted that it was legitimate for private parties to experiment with such a technology, and with local residents concerned about the effects of the light pulses on nearby oyster beds. ${ }^{46}$

Despite his contretemps with various figures of authority, Houzeau continued to develop a significant scientific career, and was elected to the Belgian Academy of Sciences. When he chose to leave for the United States shortly thereafter, it was therefore not as a political émigré or exile, but rather as an adventurer hoping to conduct botanical research on the exotic prairies of Texas. He was an example of the group that historian Romy Sánchez has described with the felicitous phrase dispersés politiques, a kind of political diaspora, even though it was not exactly politics that brought him across the Atlantic. ${ }^{47}$

43. Houzeau's political stance in the late 1840 s was variously described by his Belgian colleagues as "democratic," "republican," and favorable to "social equality." See Lancaster, Notices biographiques, xii, xi. My translation here and throughout the article.

44. Ibid., xii.

45. Ibid., xiii.

46. Ibid., xvi.

47. Romy Sánchez, "Quitter la Très Fidèle. Exilés et bannis au temps du séparatisme cubain (1834-1879)" (PhD diss., Université Paris 1 Panthéon-Sorbonne, 2016), 216. See 
Houzeau may at first have modeled himself on Alexander von Humboldt the scientist rather than on Alexis de Tocqueville the social observer, but he did not really leave his politics behind him. His enterprise as a naturalist was cut short by the secession of the state of Texas and the outbreak of the Civil War. In Texas the struggle over slavery involved plenty of violence beyond the direct confrontation of armies. From his precarious position as an unaffiliated foreign visitor, Houzeau became involved in smuggling to safety various fugitives from slavery, as well as Union soldiers who had been boxed into the Confederate stronghold. His letters home provide vivid descriptions of his adventures, and he sent back to Belgium a dramatic account published in 1862 under the title La Terreur blanche au Texas et mon évasion (White Terror in Texas and my Escape). ${ }^{48}$

In early 1863 , Houzeau made his way to Union-occupied New Orleans. From there and later from Philadelphia, he submitted contributions to L'Union. Roudanez and the activists of the later Tribune knew a good ally when they saw one, and in the autumn of 1864 this idiosyncratic but exceptionally eloquent Belgian expatriate became managing editor of the paper. ${ }^{49} \mathrm{He}$ soon showed himself to be, in the words of his biographer, "a proven radical, a compulsive worker, and a brilliant propagandist."

The Tribune had become a crucial bilingual forum for the discussion of politics, labor policy, and citizenship. The pages crafted by Roudanez, Houzeau, Trévigne, and their collaborators soon linked activists across the Atlantic, the Gulf of Mexico, and the Caribbean, adding variants of equal rights thinking into the political and social cauldron of the wartime lower Mississippi Valley, and to debates underway elsewhere in the United States.

One such international correspondent was a radical Antillean-born man of color who used the self-fashioned name Sainte-Susanne Vicomte Melvil-Bloncourt. Based in Paris, Melvil-Bloncourt wrote for the Revue du Monde Colonial Asiatique et Américain, copies of which he sent along to New Orleans. The Tribune's editors praised the pro-Union reporting of the Parisian publication, and its potential as a counterweight to pro-Confederate news that was reaching Europeans through other

also Romy Sánchez, "Le réformisme cubain et 1848. Exils croisés et circulations politiques," in Exils entre les deux mondes: Migrations et espaces politiques atlantiques au XIXe siècle, ed. Delphine Diaz, Jeanne Moisand, Romy Sánchez, and Juan Luis Simal (Paris: Éditions les Perséides, 2015), 115-42.

48. See Houzeau, Lettres, 137-283; and Jean-Charles Houzeau, La Terreur blanche au Texas et mon évasion (Brussels: $V^{\mathrm{e}}$ Parent \& Fils, 1862).

49. See Houzeau, Lettres, 303-430, at 373.

50. See the introduction by David Rankin to Houzeau, My Passage, 41. 
channels. ${ }^{51}$ They referred readers interested in subscribing to the Revue to M. V. Hébert, bookseller, whose shop was located at 131 Chartres Street in New Orleans. ${ }^{52}$

Across the next months, Melvil-Bloncourt provided the Tribune with letters to the editor assuring them of support from Europe and the French Antilles, promising to continue to raise money to assist the freedpeople, and expressing opinions on the events of the day. ${ }^{53}$ At the same time he published updates in Paris on the course of the Civil War in the United States, including the enlistment of Black soldiers in the United States army. He singled out the New Orleans Tribune and its writers for praise. He was particularly pleased with the Tribune's denunciation of unjust arrests of people of color in the streets of New Orleans, and with its insistence that Union officers show proper respect for legal procedures when recruiting soldiers. "Thus" wrote Melvil-Bloncourt, do men "once treated as helots understand their dignity and know how to defend it."

In August 1865, Melvil-Bloncourt contributed a hagiographic multipart series on the life and principles of Vincent Ogé, an early rebel against racial discrimination in colonial Saint-Domingue, and a martyr whose actions were often invoked during the Haitian Revolution by free men of color committed to equal participation in the public sphere. ${ }^{55}$ From Melvil-Bloncourt's perspective, Ogé too was a man who understood his

51. See Bryan LaPointe, "'Moral Electricity': Melvil-Bloncourt and the Trans-Atlantic Struggle for Abolition and Equal Rights," Slavery and Abolition 40 (2019): 543-62; and Willy Alante-Lima, Melvil-Bloncourt: le communard marie-galantais? (Saint-Mauredes-Fossés: Éditions Sépia, 2014). See also Melvil-Bloncourt, "A Monsieur le Rédacteur en chef de la Tribune de la Nouvelle-Orleans," La Tribune, November 15, 1864, 3, 4; "La Revue du Monde Colonial," La Tribune, November 17, 1864, 3; and "Adresse des Créoles de Couleur de la Guadeloupe," La Tribune, July 21, 1865, 1.

52. This was probably Victor Hébert, son of a Frenchman, who listed himself as a "painter" in 1860 , but seems to have taken over his father's bookshop by 1864 . See United States Census Bureau, Entry for Ward 5, New Orleans, Population Schedule for Louisiana (1860), microformed on United States National Archives, Publication No. M653, Roll 418, accessed through ancestry.com.

53. See Melvil-Bloncourt's successive letters to the editor of La Tribune, published May 19, 1865, 1; June 15, 1865, 3; July 20, 1865, 1; and July 21, 1865, 1.

54. See Melvil-Bloncourt, "Chronique de l'Amérique du Nord," Revue du monde colonial, asiatique et américain 12 (1864): 457-64. On such arrests, see John K. Bardes, "Mass Incarceration in the Age of Slavery and Emancipation: Fugitive Slaves, Poor Whites, and Prison Development in Louisiana, 1805-1877" (PhD diss., Tulane University, 2020), chs. 5, 6 (257-354).

55. See the installments of Melvil-Bloncourt, "Les Héros de la Race Africaine, Vincent Ogé," in La Tribune, August 21-24, 26-28, 30, 1865, each on page 2. On Ogé, see John Garrigus, "Vincent Ogé Jeune (1757-91): Social Class and Free Colored Mobilization on the Eve of the Haitian Revolution," The Americas 68 (2011): 33-62. 
own dignité "and knew how to defend it." ${ }^{\text {56 }}$ Melvil-Bloncourt therefore anchored the struggle for dignity in a narrative from the time of the Haitian Revolution, and sent the story off to New Orleans as the battle against distinctions of color was taking on new life in Louisiana.

The bilingual character of the Tribune was of particular importance to the process of mobilization. In January of 1865, local activists - both French-speaking and English-speaking - prepared for what was variously described as a state convention of the Equal Rights League and as the State Convention of the Colored People of Louisiana. Although French speakers were relegated to a somewhat secondary role during the Convention's deliberations, which were conducted exclusively in English, the French pages of the Tribune announced evening gatherings at a school, "L'École de Liberté," where the convention's resolutions were conveyed to the public in both English and French. ${ }^{57}$

Indeed, already on January 13 the readers of the French pages of the Tribune could follow the report of animated discussion in the convention on the question of access to the city's streetcars. General Banks, in command of federal troops in the city, had initially responded to the protest by ordering the cars to admit Black soldiers. But, insisted one delegate, is it not a disgrace for a soldier to be allowed to board, and for his mother to be refused? Calls to insist upon the broadest definition of rights were said to have been met with applause. ${ }^{58}$ When the event drew to a close, the Tribune heralded the convention as having inaugurated a "new era" of collaboration between delegates from the city and those from the rural parishes, who were said (approvingly) to have been "more radical" than their urban counterparts. With Trévigne, Houzeau, and their colleagues working back and forth between French and English in the pages of the Tribune, the dialogue about the boundaries of rights continued and expanded in scope. ${ }^{59}$

56. This phrase appears in Melvil-Bloncourt, "Les Héros de la Race Africaine, Vincent Ogé, Chapitre IX," La Tribune, August 30, 1865, 2.

57. On the convention, see the typescript transcripts available from the University of Delaware's Colored Conventions Project, http://coloredconventions.org/items/show/ 271 (accessed August 1, 2020) and Jean-Charles Houzeau, "Le journal noir, aux Etats-Unis, de 1863 à 1870 (1)," Revue de Belgique 11 (1872): 5, 21. The French pages of La Tribune announced the gathering as the convention of the "Ligue Nationale pour l'Egalité des Droits." See La Tribune, January 7, 1865, 3. See also "Réunion à l'École de Liberté," La Tribune, January 11, 1865, 3. Articles titled "Convention d'État" conveyed daily reports in French on the deliberations. See La Tribune, Jan. 10-15, 1865, each on page 3 .

58. "Convention d'État," La Tribune, January 13, 1865, 3.

59. A report on the final session was published in both the English and French pages of the Tribune on January 15, 1865. 
Later in 1865 it was Melvil-Bloncourt, writing from Paris, who reinforced the Tribune's ties to the great antislavery and equal rights campaigner Frederick Douglass. As Melvil-Bloncourt circulated petitions among Antilleans, and raised money for the freedpeople in Louisiana, he wrote to Frederick Douglass to express his admiration, and perhaps to brag a bit about the fund-raising. Douglass replied from Rochester, New York, with a long and gracious letter expressing gratitude for Melvil-Bloncourt's and other Antilleans' support for the struggle. Melvil-Bloncourt promptly forwarded the letter to the Tribune, where it appeared in the French pages on December 16, 1865, as the equal rights movement was shifting to its postwar phase. ${ }^{60}$

\section{A Constitutional Moment}

With the Confederate surrender, the assassination of Abraham Lincoln, and the beginning of the unanticipated presidency of Andrew Johnson, the editors of and contributors to the Tribune sought to regroup. They needed to keep their bearings within state politics, hold their coalition together, and propound their views nationally and internationally. The question of appropriate procedures for convening a state constitutional convention in order to re-enter the Union (given the exclusion of men of color in the state from the vote) nearly proved their undoing. In July of 1866 a group of prosuffrage activists reached for the legal fiction of "reconvening" the 1864 state constitutional convention, but this time with a new cross-racial group of informally elected delegates. As the delegates assembled in the Mechanics' Institute on July 30,1866, the mayor of the city, furious at this initiative, allowed his supporters and the police force to attack the gathering, with murderous results. More than 100 of the men in attendance were killed or seriously wounded. Jean-Charles Houzeau barely escaped with his life, and wrote a devastating account of the event to his brother in Belgium. ${ }^{61}$

The attack in New Orleans received wide coverage in the national press and brought additional discredit to President Johnson's model of a Reconstruction that would shift power to local white Unionists and exclude

60. Frederick Douglass, "Une Lettre de Frederic Douglass à Monsieur Melvil-Bloncourt," La Tribune, December 16, 1865, 1.

61. See Houzeau, Lettres, letter to his brother, dated August 5, 1866, 395-99. See also James C. Hollandsworth, An Absolute Massacre: The New Orleans Race Riot of July 30, 1866 (Baton Rouge: Louisiana State University Press, 2001); and Justin Nystrom, New Orleans after the Civil War: Race, Politics, and a New Birth of Freedom (Baltimore: Johns Hopkins University Press, 2010), ch. 2. 
people of African descent from political participation. The violence perpetrated in New Orleans under the sign of such white Unionism helped push Congress to take control of the process of political reconstruction away from the president, in favor of direct military and congressional supervision. ${ }^{62}$

In 1867, Congress placed Louisiana under federal military rule. The Reconstruction Acts of that year opened the right to vote to Black men on the same terms as white men, and called for the election of delegates for new state constitutional conventions. ${ }^{63}$ When the Louisiana convention assembled in late 1867 , it was a remarkable body. Half of the delegates were men who would be categorized as Black or "of color." Some had themselves been held in slavery just a few years earlier. Moreover, their progressive agenda ran way ahead of the minimum necessary under the law for the state to re-enter the Union. ${ }^{64}$

Several of the delegates - including Edward Tinchant-had previous affiliations with the Tribune, whose pages now carried extensive news of the proceedings. (Jean Baptiste Roudanez was also the publisher of the official report of the convention.) The paper had for months discussed ongoing campaigns to assure equal access to places "of a public character," clustering these demands along with assertions of voting rights and civil rights. Now, in late December, 1867, debate began on a new Bill of Rights. After a certain amount of wrangling, discussion moved to the precise wording of the second article, and to a proposed draft that would guarantee to all of the state's citizens the same "public rights." 65

The negative reaction from one delegate was immediate: "Mr Ludeling urged the members not to adopt any silly measure which would make this Convention the laughing stock of the world." Ludeling apparently considered that "none of these clauses could give 'social rights'; to legislate on these subjects was impossible; to adopt the term 'public rights' would afford no additional guarantees." In sum, public rights "meant nothing.",66

62. Foner, Reconstruction, 263.

63. The first statute was titled "An Act to provide for the more efficient Government of the Rebel States," and was passed by the 40th Congress on March 2, 1867.

64. On the convention, see Ted Tunnell, Crucible of Reconstruction: War, Radicalism and Race in Louisiana, 1862-1877 (Baton Rouge: Louisiana State University Press, 1984), ch. 6 and Appendix 2; and Scott and Hébrard, Freedom Papers, 121-39.

65. The official report contains very brief descriptions of the debate. See Official Journal of the Proceedings. Competing accounts of the interventions on the floor of the convention appeared in the New Orleans Times and the New Orleans Tribune during the days of the proceedings.

66. See “"This Convention.' Twenty Fifth Day, The Constitution a Night Mare," New Orleans Times, December 28, 1867, Supplement, 1. 
Edward Tinchant rose to reply: “. . . the term public rights should be made to mean something, and that everywhere a white man can go or travel the colored man should go." Judge Cooley of Pointe Coupée Parish asserted in response to Tinchant that to guarantee equal access to public accommodations was a "violation of the right of property." Much debate ensued. M. Bonseigneur, from the radical Creole wing, argued "that hotels and saloons, railroad and steamboats are open to the public, and that the proprietors thereof could make no distinctions in the regard to their guests." The reporter for the New Orleans Times, who did not conceal his animus toward the draft provision, wrote that "Mr. Cooley showed the gentleman his mistake; said that being public places they were not public property; they were private property, and the owner of them could make whatsoever disposition of them as he saw fit, provided the rights of his neighbors were not infringed." 67

The next day the argument became even more heated, with the man described by the hostile press as "Mr. Tinchant, colored" taking the lead in advocating inclusion of the phrase "public rights," along with the more familiar term "civil rights": "Civil rights not meaning the right to travel and the right to be entertained, the gentleman argued that 'all our rights' should be maintained. The law school not being open to his race, he would take the common-sense law on the subject, and interpreted 'public rights' to signify the right to be treated as one of the public without distinction of color." The reporter for the Times seemed exasperated by the whole exchange: "As the most of the speeches were but mere twaddle, it is useless to report them." 68

The Tribune's discussion of the debate took a very different tone. The writer recognized the great difficulty of trying to encompass the rights in question within the word "public": "In truth, the Convention had to deal with an order of facts that had never been enclosed before under a single word," and, therefore, it took substantial explication to clarify the "object the legislator had in view." The "neat and noble" speech by Edward Tinchant had apparently helped. The convention's vote on the wordingfifty-four in favor, sixteen opposed - could now be taken to acknowledge the full sweep of the goal: "The object of the amendment. . . is to secure the impartial treatment of all men in places of public resort. Churches, hotels,

67. The delegates were quoted — with what degree of accuracy cannot be determined - in ibid.

68. Tinchant at one point apparently invoked his personal honor, much as he had in the polemic with Lanusse 3 years earlier, "As for himself, if refused, he would still go; resisted, he would throw off his citizenship, appear as a man, and fly at the throat of the proprietor who would refuse. Under this regime the bakers might refuse to sell bread." See "Talk on Social Rights," New Orleans Times, December 29, 1867, 3. 
cars, steamboats, theaters, stores, even schools are intended to be embraced in that amendment, in the meaning of its authors." 69

In its final version, the new constitution contained both the second article of the Bill of Rights, including the phrase "public rights," and Article Thirteen, which laid out the antidiscrimination provisions in detail. Jean-Charles Houzeau, although exhausted from the political and journalistic work that had accompanied the convention, wrote with satisfaction to his parents on February 3,1868, that this would be a constitution "qui consacre les droits des citoyens de toutes les couleurs" (which establishes the rights of citizens of all colors)..$^{70}$

No sooner had the convention concluded, however, than the coalition that had brought it into existence came under threat. When their favored candidate failed to obtain the nomination of the Republican Party for the upcoming gubernatorial elections, which went to the Northern-born white Republican Henry Clay Warmoth, the primary backers of the Tribune advocated running a third-party slate. Houzeau argued that this would be a catastrophically divisive strategy. He did not prevail. ${ }^{71}$

Just weeks after the conclusion of the Constitutional Convention, Houzeau announced to his parents that he would soon leave New Orleans to resume his project of visiting Jamaica. His summary of the conflict over election strategy was severe: "mes amis, trop français en Amérique, seront battus aux élections, et tueront leur influence à jamais." ("My friends, too French in America, will be defeated in the elections, and will kill their influence forever.") He also feared that by opposing the candidacy of Warmoth his allies had opened up a split between those he characterized as freeborn mulattres (people perceived as of mixed ancestry) and the newly freed Black population, who were expected to vote in large numbers for the Republican nominee. In sum, Houzeau was frustrated at the unfolding political debacle, weary of the burden of editing the paper, and eager to resume his scientific work. ${ }^{72}$

Elections in April of 1868 brought a ratification of the state constitution, but victory in the gubernatorial election went to the Tribune's nemesis, the conservative Republican Henry Clay Warmoth. ${ }^{73}$ The Tribune promptly

69. See "Constitutional Convention," The Tribune, December 29, 1867, 4.

70. Houzeau, Lettres, 427.

71. Houzeau's analysis of the election strategy appears in a letter to his parents dated March 2, 1868. Ibid., 427-28.

72. Ibid.

73. Donald W. Davis, "Ratification of the Constitution of 1868-Record of Votes," Louisiana History: The Journal of the Louisiana Historical Association 6 (1965): 301-5. In his memoirs, Warmoth denounced the leadership of the Tribune as "three San Domingo negroes" who were part of a "Pure Radical" party that sought to create an 
lost its contract as the state's official publisher (a lifeline for any nineteenth-century newspaper). The combination of Warmoth's election and Houzeau's departure for Jamaica brought a remarkable phase of bilingual activist journalism to a conclusion. The last regular issue of the paper appeared on April 25, 1868, although it was briefly revived in $1869 .{ }^{74}$ As Houzeau had feared, the fracture had indeed undercut the power of the Creole radicals.

\section{From Constitutional Concept to Practical Legislation}

Despite the electoral setbacks to the cosmopolitan progressives of the Tribune, the 1868 constitution that they had helped to shape was now in place. Moreover, a state legislative coalition in favor of guaranteeing equal treatment in public life had expanded and consolidated. Putting aside initial concerns about the risks of asserting what could be construed as a claim to "social equality," the early postwar legislators would use their authority under the state constitution to name and prohibit the dignitary affront that lay behind refusals of equal service on the grounds of color. ${ }^{75}$

In late 1868, the Louisiana legislature passed a detailed antidiscrimination statute. Initially titled a bill "to protect all persons in their civil and public rights," it drew support from both French-speaking and English-speaking delegates, including some who had previously been hesitant to legislate in this area. It was nonetheless vetoed by Governor Warmoth, who was seeking support from white Unionists. ${ }^{76}$

The legislature persisted, and resumed debate on a similar bill, more discreetly titled an "Act to enforce the Thirteenth Article of the Constitution of this State, and to regulate the Licenses mentioned in said Thirteenth Article." The hostile press still referred to it as the "so-called civil rights

\footnotetext{
"African state government." Henry Clay Warmoth, War, Politics and Reconstruction: Stormy Days in Louisiana (New York: Macmillan, 1930), 51-52.

74. Roudané, The New Orleans Tribune, also mentions some weekly issues in 1870.

75. On the composition of these postwar legislatures, see Charles Vincent, Black Legislators in Louisiana during Reconstruction (Baton Rouge: Louisiana State University Press, 1976), 71-113. See also Roger A. Fischer, The Segregation Struggle in Louisiana, 1862-1877 (Urbana: University of Illinois Press, 1974). On the contemporaneous struggles over labor rights, see Rebecca J. Scott, Degrees of Freedom: Louisiana and Cuba after Slavery (Cambridge, MA: Harvard University Press, 2005); and John C. Rodrigue, Reconstruction in the Cane Fields: From Slavery to Free Labor in Louisiana's Sugar Parishes, 1862-1880 (Baton Rouge: Louisiana State University Press, 2001).

76. The first bill was introduced by Representative R. H. Isabelle of Orleans Parish and was passed by the General Assembly in September of 1868. See "The General Assembly," New Orleans Times, September 19, 1868, 3. On its veto, see Vincent, Black Legislators, 92-93.
} 
bill." Those who were sympathetic called it simply the "civil rights bill." Legislators were thus expanding the scope of the phrase "civil rights" to encompass the sweeping dignitary principles that they had initially embraced as "public rights." An editorial in the revived Tribune explained the need for such a statute, noting that under the "present order of things" the "broad stamp of inferiority is put upon us." The terminology of the Louisiana discussion converged with legislative efforts underway in other states where the expansion of the electorate had brought proposals for civil rights bills to the fore. After a certain amount of back and forth, the legislature passed a revised bill that omitted the criminal penalties of the earlier one. Governor Warmoth grudgingly signed it in February of $1869 .^{77}$

The new statute provided a cause of action under which individuals could bring suit, and authorized claims for "exemplary" damages. In effect, the legislature was identifying racial discrimination in public spaces as a harm that directly injured the individual victim of such treatment: what philosopher Stephen Darwall has analyzed as the "second-personal" character of dignitary offenses. It was not just that the behavior should be prohibited by a rule enforceable by a third party, but also that the injured party had a right to demand individual redress. ${ }^{78}$ Although many among the state's judges had little or no personal affection for the concept of equal public rights, they would now find lawyers coming to court armed with a quite explicit statute. Republican attorneys and activists such as Simeon Belden, born in Louisiana, were available to represent potential plaintiffs. When Charles Sauvinet was refused service at a local tavern in 1871, he brought suit and recovered damages. ${ }^{79}$

In those same years another lawyer arrived in New Orleans, armed with legal acumen and a cosmopolitan outlook. The son of a mother who had escaped from slavery, Thomas Morris Chester from Harrisburg,

77. Vincent, Black Legislators, 92-96, quotation from the Tribune at 96. Discussion of the second round of legislative debate can be found in the New Orleans Crescent, February 20,1869, 4, which deemed the bill an "ill-timed, tyrannical, and infamous measure;" and in the Tribune, February 23, 1869, 1. Edwards, in A Legal History of the Civil War and Reconstruction, 131, observes that during Reconstruction African Americans "stretched the framework of rights" and "turned issues that had been considered social rights into civil rights."

78. La. Rev. Stat. No. 38 (1869) Sect. 4; Stephen Darwall, "Equal Dignity and Rights," in Dignity: A History, ed. Remy Debes (New York: Oxford University Press, 2017), 182-201. Thomas C. Holt emphasizes the crushing everyday dignitary offenses involved in forced segregation. See Holt, The Movement: The African American Struggle for Civil Rights (New York: Oxford University Press, forthcoming, 2020).

79. The case reached the Louisiana Supreme Court as Sauvinet v. Walker, 27 La. Ann. 14 (La. 1875) and the United States Supreme Court as Walker v. Sauvinet, 92 U.S. 90 (1875). 
Pennsylvania had become a schoolteacher in Liberia and a student of law at the Inns of Court in London. He accompanied the Union Army as a correspondent through the final campaign into Virginia, and recalled having written one of his dispatches from the very desk at which Jefferson Davis had once sat. In 1869 the Christian Recorder reported that T. Morris Chester was "lionizing quite extensively in Europe," and had recently been the guest of the Democratic Union in Frankfurt, Germany. ${ }^{80}$

By 1870 the now seasoned Chester was ready to establish a legal practice in the United States. He chose New Orleans, where the 1869 antidiscrimination statute enabled public rights to be defended in court, while the practices of white supremacy guaranteed that there would be cases to bring. Chester's name soon appeared as counsel for plaintiffs who had been subjected to exclusion or unequal service. Some of them were modestly situated individuals who had been refused a seat at the table in a soda shop, rather than the better-known litigants such as Charles Sauvinet, who had held public office as civil sheriff of the city. Chester argued their cases vigorously, and word seems to have spread that refusal of service on the grounds of color could bring a lawsuit. ${ }^{81}$

\section{Challenging an Affront to Dignity}

While Thomas Morris Chester was lining up ordinary litigants to exercise their rights under the law, one of the most conspicuous efforts to enforce Article 13 of the Constitution was under way from what might be thought to be a curious quarter, a woman of color whose husband had been a largescale slaveholder. In eighteenth- and early-nineteenth-century Louisiana, some white fathers manumitted children born to their enslaved intimate partners, on occasion providing those partners and their children with legacies of land. Astute management and a fortunate marriage could increase an original endowment across subsequent generations. A few men and

80. See Thomas Morris Chester, Thomas Morris Chester, Black Civil War Correspondent. His Despatches from the Virginia Front, edited, with a biographical essay and notes, by R. J. M. Blackett (Baton Rouge: Louisiana State University Press, 1989), 1-91; and the article in the Christian Recorder, July 3, 1869, as transcribed in the database "Accessible Archives," http://www.accessible-archives.com/collections/african-americannewspapers/the-christian-recorder/

81. Beth Kressel Itkin found Chester listed as the lawyer for several plaintiffs seeking to enforce Louisiana's 1869 antidiscrimination statute. See Beth Kressel Itkin, "Creating 'What Might Have Been a Fuss': The Many Faces of Equal Public Rights in Reconstruction-era Louisiana," Louisiana History: The Journal of the Louisiana Historical Association 56 (2014): 42-74. Chester's legal practice is discussed by Blackett in Chester, Thomas Morris Chester, 72-74, 87. 
women of color in the sugar and cotton parishes thus became substantial holders of land and enslaved persons. Among them were Antoine Decuir II and Josephine Dubuclet, who married in 1835. In 1860, the census counted 112 persons enslaved on their plantations in Pointe Coupée Parish. $^{82}$

During the Civil War, the Decuirs mortgaged their properties and their future crops, and Josephine Decuir left for France. We know little about her time in France, beyond her later statement that she had been "treated there like a white lady." Near the close of the war, Antoine Decuir II died. Josephine Decuir returned to Louisiana to settle his estate, a task that would require her to travel from New Orleans up the Mississippi River to Pointe Coupée Parish. ${ }^{83}$

In 1866, Decuir purchased cabin passage on the steamboat Lafourche. The captain assigned her to a room that he used for such occasional prosperous persons of color as might desire private accommodation. The door on one side connected with the "guards," a passageway along the deck. A second door led to a heated general "cabin" or sitting area, onto which the staterooms for the use of "white ladies" opened. During the voyage, Decuir left her room and entered the main ladies' cabin to take a seat in a rocking chair. Upon learning of this, the captain sent word that she was not to enter the cabin area, but was to keep to her room. Mortified, Decuir promptly sent for the captain. She "was in tears and crying" and told him that she did not accept such treatment from him "as I had known her husband so long, and so forth." "I told her that I had to have these rules and regulations and that I could not permit her in that cabin." On subsequent trips, the captain apparently locked the door leading from her room into the main cabin. Captain Barranco later testified that she had told him that she "had been in France a good while, and was treated there like a white lady. I told her I

82. See Brian J. Costello, A History of Pointe Coupée Parish, Louisiana (Donaldsonville, LA: Margaret Media, Inc., 2010), 102, 106-7, 132; Loren Schweninger, "Antebellum Free Persons of Color in Postbellum Louisiana," Louisiana History 30 (1989): 345-64; Charles Vincent, "Aspects of the Family and Public Life of Antoine Dubuclet: Louisiana's Black State Treasurer, 1868-1878," The Journal of Negro History 86 (1981): 26-36; and Jack Beermann, The Journey to Separate but Equal: Madame Decuir's Quest for Racial Justice in the Reconstruction Era (Lawrence: University of Kansas Press, forthcoming, 2021). I have greatly benefitted from discussions with Jack Beermann about the case.

83. See the testimony of the steamboat captain Barranco, in Transcript of Record, Mrs. Josephine Decuir v. John G. Benson, Eighth District Court for the Parish of Orleans, No. 7800, transferred to Fifth District Court, No. 4028, reproduced in United States Supreme Court Records and Briefs, Docket No. 294, John G. Benson v. Josephine Decuir (hereafter TR, Decuir v. Benson, USSC), Testimony of Captain V. B. Barranco, 32-41. (After the case went on appeal to the United States Supreme Court, Benson died and the case was taken over by his heirs. The final decision is therefore styled Hall v. Decuir.) 
couldn't help that; that it was a custom here to keep colored people separate from the whites, and that she would have to abide by that rule or not travel on the boat. That was the end of it. She kept her place from that out." 84

Josephine Decuir's implied appeals to feminine delicacy and family connections, combined with her background of slaveholding wealth and European exile, may make her claim to equal rights (and privileges) less than stirring for some modern readers. Upon return from France, however, Decuir was facing the prospect of an abrupt vertical fall in status accompanied by financial ruin and humiliating rejection. The question of her treatment in public was part and parcel of the maintenance of her reputation. One of her acquaintances, P. G. Deslonde, testified in court that Mme. Decuir "is very much of a lady and always has been." For his own part, Deslonde refused to accept consignment to the area of a steamboat that the crew referred to sarcastically as the "freedmen's bureau." ("It is a black room somewhere in the back part of the boat where they generally pen up colored passengers.") He opted to avoid humiliation by instead standing on deck through the evening. ("I travelled often without taking any meals on a boat where I discovered there were prejudices.") Josephine Decuir, however, was well aware that for a woman to maintain her respectability required proper withdrawal and seclusion at nighttime. ${ }^{85}$

In 1872 Josephine Decuir again needed to take the journey to Pointe Coupée. She was to conduct business there along with two New Orleans lawyers, E. K. Washington and Seymour Snaer, whom she had hired to examine legal papers pertaining to her husband's estate. Washington professed to be unaware that given her family background, his client would in Louisiana be termed a "woman of color." He therefore anticipated no difficulty in obtaining private cabin accommodations for her on the steamboat called the Governor Allen, under Captain Benson. And here the difficulty began: the agent refused to issue a ticket for Mme. Decuir to travel in a

84. TR, Decuir v. Benson, USSC, testimony of Captain V. B. Barranco, 32-41.

85. See the testimony of P. G. Deslonde in TR, Decuir v. Benson, USSC, 64-69. (In 1873, at the time that he provided testimony, Deslonde was Louisiana's secretary of state.) A generation of scholars of women's history have traced African American women's efforts to negotiate propriety as they moved through a world filled with risks to their dignity and safety. See Elsa Barkley Brown, "Negotiating and Transforming the Public Sphere: African American Political Life in the Transition from Slavery to Freedom," Public Culture 7(1994): 107-46; Martha S. Jones, All Bound Up Together: The Woman Question in African American Public Culture, 1830-1900 (Chapel Hill: University of North Carolina Press, 2007); Hannah Rosen, Terror in the Heart of Freedom: Citizenship, Sexual Violence, and the Meaning of Race in the Postemancipation South (Chapel Hill: University of North Carolina Press, 2009); LaKisha Simmons, Crescent City Girls: The Lives of Young Black Women in Segregated New Orleans (Chapel Hill: University of North Carolina Press, 2015); and Masur, An Example for All the Land. 
stateroom on the upper deck, citing her color as his reason. Washington realized the embarrassing situation that lay ahead, and urged his colleague Seymour Snaer to alert Decuir, who had already boarded the boat. The message apparently did not reach her. ${ }^{86}$

Once the overnight journey was underway, Josephine Decuir was told by the staff that she could not have a room in the "ladies cabin." She could repair to the "Bureau"- a poorly ventilated space in the stern otherwise referred to as "the colored department" - or to the "chamber-maid's department." Decuir refused. Instead, she spent the overnight journey in the "recess," a "small compartment" at the rear of the boat accessible to some members of the crew and to the chambermaids. The steward had set up a cot there, but she refused to disrobe and sleep in such an exposed location. When they arrived at Hermitage Landing, she paid her fare and expressed her distress to the clerk. He later said that he averted his gaze, "for fear of laughing." $" 87$

Shortly after they returned to New Orleans, Washington and Snaer filed suit on Decuir's behalf in the Eighth District Court of Orleans Parish alleging a violation by Captain Benson of Article 13 of the state's constitution and of the state's 1869 statute on public accommodations and common carriers. ${ }^{88}$ Her petition formally averred that "in all her travels on different steamers and public conveyances, both in this country and Europe, she had not met a like indignity as on the steamer Governor Allen." $" 89$

After consulting the extensive testimony, the judge ruled in favor of Decuir, considering her treatment to have been a clear violation of the 1869 law. He awarded her $\$ 1,000$ in actual damages, as well as court costs, to be paid by Benson, though he declined to order the payment of the additional "exemplary damages" that she had sought. Captain Benson, with the support of other steamboat owners, appealed the case

86. TR, Decuir v. Benson, USSC, testimony of D.E. Grove, 23-29; testimony of E. K. Washington; and testimony of Seymour Snaer [his surname is misspelled in the print transcript], 72-73.

87. See TR, Decuir v. Benson, USSC, including Petition of Mme. Antoine Decuir, 1; testimony of J. H. Mossof, describing a "recess" as "a place for children to play in more than anything else, and servants to stay, and the like of that. There are no accommodations there for sleeping or anything of that kind." 9; testimony of the clerk D. E. Grove, describing events on board the Governor Allen, 24, 26, 28; testimony of Barranco, on the "freedmen's bureau" or "colored department," 38; testimony of the steward John Cedilot, 50.

88. Washington and Snaer were law partners with Simeon Belden, who had been a member of the Constitutional Convention of 1867-68. On the partnership, see Mary Frances Berry, We Are Who We Say We Are: A Black Family's Search for Home Across the Atlantic World (New York: Oxford University Press, 2015), 92-94.

89. TR, Decuir v. Benson, USSC, Petition of Mme. Antoine Ducuir, 1. 
to the Louisiana Supreme Court. It was docketed quickly, under the terms of an 1870 state law that gave civil rights cases on common carriers a priority. ${ }^{90}$

The majority of the justices backed Josephine Decuir, and rejected the defendant's argument that the exclusions had been mere reasonable regulations: "[I]t cannot be pretended that a regulation which is founded on prejudice \& which is in violation of law is reasonable." Their colleague William G. Wyly, however, dissented vigorously. He believed the state law to be incompatible with the United States Constitution's Commerce Clause, which granted regulatory power over interstate commerce to the federal government. Although Decuir's journey was from one point in Louisiana to another, the boat itself would later make landings in Mississippi. Wyly invoked the potential confusion if adjacent states were to diverge in their laws on the providing of separate cabins. At the same time, he implied that Josephine Decuir's claims were ill-intentioned, citing the captain's testimony that his clerk had reported on the day of the journey in question that "there was a woman on board of the boat disposed to make a little trouble if she could." $" 91$

In its decision, the state supreme court, as arbiter of the meaning of the state's constitution and statutes, acknowledged and enforced the guarantee of equal public rights. Monetary damages (albeit reduced) were to be paid to remedy the affront. A refusal to provide equal service, based on a distinction of color, was impermissible. ${ }^{92}$

90. The statute is La. Rev. Stat. No. 39 (1870), repealed 1902. I thank Jack Beermann for noting that other steamboat owners appear on the appeal bond for Benson. TR Decuir v. Benson, USSC, 82-83.

91. Decuir v. Benson, 27 La. Ann. 1 (La. 1875); and TR, Decuir v. Benson, USSC, testimony of John Benson, 42. Familiar figures from the Constitutional Convention of 1867 now sat on the court, including John T. Ludeling, whom the Times had quoted as saying that "public rights mean nothing," and James G. Taliaferro, who had presided over the convention, and had been supported by Roudanez in the gubernatorial election of 1868 . See Evelyn L. Wilson, The Justices of the Supreme Court of Louisiana, 1865-1880 (Lake Mary, FL: Vandeplas Publishing 2015), 63-154.

92. The potential Commerce Clause problem posed by the application of Louisiana's antidiscrimination law to a steamboat on the Mississippi River had been left aside, consistent with the unsettled state of Commerce Clause jurisprudence as of the early 1870s. One scholar notes that the case "came to a Supreme Court still in search of a clear set of dormant Commerce Clause rules." Joseph R. Palmore, "The Not-So-Strange Career of Interstate Jim Crow: Race, Transportation, and the Dormant Commerce Clause, 1878-1946," Virginia Law Review 83 (1997): 1773-817. For a recent analysis of the case in the context of the Commerce Clause, see Beermann, The Journey to Separate but Equal. 


\section{The White-Supremacist Counterattack}

Josephine Decuir had by this point become a target for a powerful New Orleans-based legal team that sought to thwart all such claims of right, both in Louisiana and nationally. R. H. Marr, a skilled lawyer, a distinctive public figure, and a vocal proponent of white supremacy, stepped up to become co-counsel for the heirs of the steamboat owner in an appeal of Decuir v. Benson to the United States Supreme Court. ${ }^{93}$ Marr embodied the adroit combination of litigation and mobilization that characterized the white-supremacist counteroffensive. Indeed, just a few months after the appeal was filed, he would exhort the armed members of the White League to attack the offices of Governor Kellogg in what became a (briefly) successful coup d'état against Republican rule. ${ }^{94}$

By 1874 , those who sought to defend the legitimacy of the public rights guarantees in the state constitution faced a daunting array of legal enemies. Instead of being undercut by the previous hostile white Republican governor Warmoth, or abandoned by their eloquent European ally Jean-Charles Houzeau, they were now directly challenged by a lineup of formidable legal talent with an eye on national policy. Conservative lawyers, supported by a significant portion of the city's elite, were systematically attacking each component of the radical Reconstruction project. The decision in the 1873 Slaughterhouse Cases had enabled conservatives to narrow the scope of the "privileges and immunities" deemed to accompany federal citizenship, while the appeal of the convictions of several vigilantes in the case called U.S. $v$ Cruikshank could undermine federal protections against violence aimed at voters. (Marr also served as attorney for the defendants in Cruikshank. $)^{95}$ Attacking the case of Josephine Decuir offered the possibility of sharply diminishing the value of the public rights

93. Marr had earlier provided assistance to Benson's attorney in preparing petitions to the Louisiana Supreme Court. See Beermann, The Journey to Separate but Equal. On the anti-equal-rights bar in Louisiana, see Michael Ross, "Obstructing Reconstruction: John Archibald Campbell and the Legal Campaign against Louisiana's Republican Government, 1868-1873," Civil War History 49 (2003): 235-53.

94. For background on R. H. Marr, see Charles Lane, The Day Freedom Died: The Colfax Massacre, the Supreme Court, and the Betrayal of Reconstruction (New York: Henry Holt \& Co., 2008), 155-57; and Rebecca J. Scott, "Social Facts, Legal Fictions, and the Attribution of Slave Status: The Puzzle of Prescription," Law and History Review 35 (2017): 9-30. On Marr's behavior at the September 1874 Battle of Canal Street, recounted by his admirers, see Louisiana State Museum, Carpet-Bag Misrule in Louisiana: The Tragedy of the Reconstruction Era Following the War Between the States (New Orleans: Louisiana State Museum, 1938), 40-42.

95. See Ross, Obstructing Reconstruction, 241-51; and Lane, The Day Freedom Died, 156-57, and passim. 
provisions in Louisiana's 1868 Constitution, and of reducing the scope of enforcement of state antidiscrimination statutes in Louisiana and elsewhere.

Equal-rights activists now had little choice but to fight a set of defensive actions against homegrown and self-declared white supremacists, from vigilantes to lawyers to lawyer-vigilantes such as R. H. Marr. Marr was poised to insist that separating passengers on the basis of color was a mere reasonable business practice, not covered under a state law that prohibited exclusion or expulsion on the basis of color. Moreover, although Josephine Decuir had been traveling entirely within Louisiana, the steamboat itself was on an interstate journey, and the state law might be thought to encroach on a federal prerogative.

In the final decision of the U.S. Supreme Court, Chief Justice Waite agreed with the earlier dissent by Louisiana's Justice Wyly, characterizing the Louisiana statute as imposing "a direct burden upon inter-state commerce." Waite envisioned the moment when a boat coming down the Mississippi entered the state of Louisiana: "A passenger in the cabin set apart for the use of whites without the state must, when the boat comes within, share the accommodations of that cabin with such colored persons as may come on board afterwards, if the law is enforced." For Chief Justice Waite, it was self-evident that the antidiscrimination statute from Louisiana, rather than segregationist practice in Mississippi, was the source of the conflict. ${ }^{96}$

White supremacists had chosen wisely when they took on this case, rather than targeting the more familiar damage awards for episodes of refusal of service at restaurants and bars. ${ }^{97}$ In effect, given the interstate itinerary of the Governor Allen, the state antidiscrimination law had been enforced on Decuir's behalf against Benson in a sphere in which federal authority was potentially greatest. ${ }^{98}$ The United States Supreme Court's decision could therefore rest on a complacent acceptance of the reasonableness of racial discrimination, combined with deference to the prohibitory power of the Commerce Clause. ${ }^{99}$

96. Hall v. Decuir, 95 U.S. 485 (1877), 488-89.

97. Charles Sauvinet, who had been refused service at a bar in New Orleans, won damages in the Louisiana courts, which were then upheld on appeal to the United States Supreme Court in 1876. The procedural posture in that instance, however, was quite different. Those attacking Sauvinet's victory claimed the right to a jury trial in a civil case, and failed to prevail on that claim. Walker v. Sauvinet, 92 U.S. 90 (1876).

98. The federal Civil Rights Act of 1875-which itself might have been invoked against the steamboat owner - was not directly applicable to Hall v. Decuir, having been passed after the episode on the Governor Allen.

99. Twelve years after the issuance of the decision in Hall v. Decuir, the Louisiana state legislature passed a bill imposing separation by color, rather than prohibiting it. A new generation of equal-rights activists, well aware of the Hall $v$. Decuir precedent, immediately 
The ruling did not, in itself, invalidate Louisiana's 1869 law as applied to purely in-state activities. Committed plaintiffs, sheriffs, and prosecutors could have continued to identify violators in order to bring civil suits, impose fines, and initiate the revocation of licenses when service was denied at taverns, theaters, or retail stores. But by January 1878, when the decision was issued, the practical prospects for enforcement of the law in an intrastate context were dimming rapidly as political power in the state shifted to proponents of white supremacy.

The resolution of the disputed federal election of 1876 had brought the withdrawal from the state of nearly all of the remaining federal troops whose presence had offered some hope of protection for Black voters seeking to register and cast ballots. The contested victories of Democrats in the state elections were allowed to stand. What Southern Democrats called "redemption" from unwelcome federal intrusion was at hand. ${ }^{100}$ One could, of course, point out the irony of "states' rights" Democrats welcoming the United States Supreme Court's expansion of federal Commerce Clause jurisdiction in Hall v. Decuir in order to defeat the state's antidiscrimination statute. But as scholars have often noted, formal arguments in this domain have historically been saturated with prior commitments on matters related to race. ${ }^{101}$

When a Democratic governor took office in 1877 , he peremptorily turned out the former members of the state supreme court, and named new ones. R. H. Marr, instigator of the coup d'état led by the White League in 1873, now took a seat on the court. ${ }^{102}$ When the case of Hall

challenged the 1890 Separate Car Act (Act 111, 1890) as unconstitutional. Their challenge proved successful in a test case that dealt with a journey (undertaken by Daniel Desdunes, son of one of the activists) that was itself explicitly interstate. The activists' concurrent challenge based on an intrastate journey, however, famously went down to defeat in Plessy v. Ferguson. See Keith Weldon Medley, We as Freemen: Plessy v. Ferguson (New Orleans: Pelican Publishing Companies, 2003). On the multiple dimensions of these struggles, see Barbara Welke, "When All the Women Were White, and All the Blacks Were Men: Gender, Class, Race and the Road to Plessy, 1855-1914," Law and History Review 13 (1995): 261-316.

100. A classic older account of Reconstruction instability in the state can be found in Joe Gray Taylor, Louisiana Reconstructed 1863-1877 (Baton Rouge: Louisiana State University Press, 1974). An astute modern interpretation is Lawrence Powell, "Centralization and its Discontents in Reconstruction Louisiana," Studies in American Political Development 20 (2006): 105-31.

101. On this point, see, among others, Richard A. Primus, "The Riddle of Hiram Revels." Harvard Law Review 119 (2006): 1680-734.

102. Marr was joined on the court by Alcibiades De Blanc, a founder of the Knights of the White Camellia, one of Louisiana's main white supremacist vigilante groups. See James K. Hogue, Uncivil War: Five New Orleans Street Battles and the Rise and Fall of Radical Reconstruction (Baton Rouge: Louisiana State University Press, 2006), 126, 167. 
v. Decuir came back onto the Louisiana Supreme Court docket in April of 1878 as a result of the United States Supreme Court's judgment to reverse and remand, Marr would have the great satisfaction of executing the mandate on the case that he had himself argued as attorney for the successful appellant. Unsurprisingly, the Louisiana court now formally canceled the damages award and ordered Josephine Decuir to pay to the heirs of the steamboat owner all court costs from the suit and the two appeals. ${ }^{103}$

One of the first items of business of the new Democratic state government was to get rid of the 1868 Constitution. Once a replacement constitution was ratified in 1879, the state's fundamental law no longer carried any reference to "public rights." 104 The 1869 Louisiana public rights statute remained on the books, but became a dead letter. When the issue of equal accommodations on common carriers was reopened following World War II, the surviving statute came to the attention of Louisiana legislators, who proceeded to repeal it. ${ }^{105}$

\section{Conclusion}

The legal and political debate on Louisiana's constitutional guarantee of equal public rights had lasted for more than a decade and encompassed a wide cast of characters, from cosmopolitan journalists and letter writers to local voters, lawyers, and litigants. The participants in that debate drew on multiple bases of support and varied political traditions. Edward Tinchant followed in the footsteps of his cigar merchant older brother Joseph to rally to the Union cause in New Orleans, and then built his political base as a schoolteacher, a veteran, and the head of a local branch of the national veterans' group The Grand Army of the Republic (G.A.R.). ${ }^{106}$ Jean-Charles Houzeau, whose early engagement with the thought of Fourier and organizing work in 1848-49 gave his politics an egalitarian bent, seized the opportunity to put into eloquent journalistic prose the political and ethical logic behind equal public rights. Sainte-Susanne Melvil-Bloncourt had gained rhetorical skills as a student activist, which he drew upon as he boldly wrote letters to those whom he envisioned as his peers on the other side of the Atlantic. (Melvil-Bloncourt would in

103. I thank Jack Beermann for having shared a photograph of a copy of the mandate sent to the Louisiana Supreme Court, and the dispositions then ordered, as preserved in the City Archives, Louisiana Division, New Orleans Public Library.

104. Constitution of the State of Louisiana Adopted in Convention at the City of New Orleans, the Twenty-Third Day of July, A. D. 1879 (New Orleans: Jas. H. Cosgrove, 1879).

105. La. Rev. Stat. No. 38 (1869). Repeal in La. Acts 1954, No. 194, § 1.

106. On Tinchant's involvement with the G.A.R., see Scott and Hébrard, Freedom Papers, 125. 
1874 be charged and sentenced to death in absentia for his participation in the Paris Commune. ${ }^{107}$ ) Paul Trévigne, Simeon Belden, Seymour Snaer, Robert Isabelle, and many others brought local knowledge and deep Louisiana roots to the struggle. Working with newspapers from across the country that eagerly reprinted each other's articles, their campaigns could draw upon similar struggles underway in other jurisdictions, North and South. ${ }^{108}$

For many of these activists, their formal principles meshed well with the occasion. Edward Tinchant's account of threats to his own honor could make vivid the affronts to dignity inherent in expulsion from a whites-only streetcar. Jean-Charles Houzeau explicated the new language of the 1868 Louisiana Constitution by invoking the dignitary underpinnings of the concept of public rights. From further afield, the readers of the Tribune could see in Melvil-Bloncourt's capsule biography of Vincent Ogé a revolutionary champion of dignité.

The situation was somewhat different for Josephine Decuir. To understand her role it may be helpful to step away from the search for consistent radical ideas, and instead look at the way that experience can embody a concept. A woman who found herself "at odds with her circumstances," Decuir sought respect based in part on her prewar prosperity and privilege, in part on a sense of herself reinforced by her time in Paris, and in part on the state's constitution. ${ }^{109}$ She was not given to the egalitarianism of quarante-huitards such as Tinchant, Houzeau, and Melvil-Bloncourt. Indeed, her internal sentiments about those who had once been enslaved probably reinforced her unwillingness to be relegated to the space on a steamer that the crew referred to as the "Bureau," a mocking reference to the federal Freedmen's Bureau. But Josephine Decuir and her lawyers knew that the humiliation imposed upon her by the steamboat captain was part of a larger project of establishing white supremacy, a project that would threaten not just the dignity of Decuir, but that of any person of African ancestry who sought to exercise the public rights guaranteed in the state's constitution. ${ }^{110}$

107. See "Dernières Nouvelles," Le Petit Journal, June 7, 1874, 1.

108. On the activities of Isabelle, Trévigne, and Belden, which included litigation in pursuit of school integration, see J. Morgan Kousser, "Before Plessy, before Brown: The Development of the Law of Racial Integration in Louisiana and Kansas," in Toward a Usable Past: Liberty under State Constitutions, eds. Paul Finkelman and Stephen E. Gottlieb (Athens, GA: University of Georgia Press, 1991), 213-70.

109. I have borrowed the idea of a woman "at odds with her circumstances" from Penelope Fitzgerald, Consequences (New York: Penguin Group, 2007), 1.

110. An article had made this point during the initial discussion of the statute: "When one or a few colored men are excluded from certain public rights enjoyed by all white men, not 
Some years after he left New Orleans, Jean-Charles Houzeau looked back on his experience, and tried to capture the embodied sense of a right to equal treatment that his colleagues there had developed: "After having been witness in France or England to the liberality of institutions, after having there enjoyed civil equality, they could no longer bear with patience the exceptional and debasing yoke of the Black Code."111 Houzeau's rhetorical flourishes notwithstanding, exposure to such "liberality" in another land was not a precondition for rights-consciousness. Edward Tinchant, born in France, had indeed helped craft and argue for the language of equal "public rights" that appeared in the 1868 constitutional text. But most of the voters who ratified that document had lived their entire lives in Louisiana. Like many of their fellow citizens elsewhere in the Reconstruction South, they knew that disrespect in public space undermined their rights in many spheres.

As Louisiana's activists developed the rationale for public rights, and then folded those public rights into an expanded sense of civil rights, they anchored their arguments in a claim to dignity. Building on a longstanding European tradition of a protectable legal interest in personal honor, but also fully aware of the interlocking components of the looming white-supremacist project, they pioneered conceptual language on the state's responsibility to protect citizens' rights to public respect. ${ }^{112}$

The cross-racial composition of the 1867-68 Constitutional Convention had mitigated the deficits of legitimacy that often undercut moments of transitional lawmaking. Louisiana's delegates won election under the expansive suffrage that accompanied the 1867 Military Reconstruction Acts. At the initiative of delegates of color, Louisiana's convention in turn went beyond the oblique language that had been crafted by the federal

the few alone but the entire colored population are wronged." The Tribune, February 14, $1869,4$.

111. "Après avoir été témoins en France ou en Angleterre de la libéralité des institutions, après y avoir joui de l'égalité civile, ils ne pouvaient plus porter qu'avec impatience, le joug unique et flétrissant du Code Noir." See Houzeau, "Le journal noir . . . (Part I)," 8. The term "Code Noir" was often used to refer generically to regulations governing persons of African descent, and not just to the specific French-language texts bearing that name.

112. For the generations of Louisiana activists who followed, this legacy of Reconstruction became a memory to be nourished across ensuing long years of legal defeat. On continuities into the 1890s, see Joseph Logsdon with Lawrence Powell, "Rodolphe Lucien Desdunes, Forgotten Organizer of the Plessy Protest," in Sunbelt Revolution: The Historical Progression of the Civil Rights Struggle in the Gulf South, 1866-2000, ed. Samuel Hyde, Jr. (Gainesville: University Press of Florida, 2003), 42-70. On the early and mid-twentieth century, see Rachel L. Emanuel and Alexander P. Tureaud, Jr., A More Noble Cause: A. P. Tureaud and the Struggle for Civil Rights in Louisiana (Baton Rouge: Louisiana State University Press, 2011), 5, 8, 19. 
Congress for the Fourteenth Amendment. While cherishing the possibility of an expanded federal citizenship, the new lawmakers took the opportunity of state constitution-making to spell out specific positive rights that they saw as essential to full civil freedom. And at the center, they placed their insistence that the state had an obligation to assure that they would not be subjected to forced indignity in the public sphere. 